\title{
Kakovost življenja v soseskah, ki se prenavljajo: primer iranskega mesta Mašad
}

Propadanje mestnih predelov je eden najbolj perečih izzivov v razvoju mest, zaradi katerega se stara mestna območja spopadajo z resnimi družbenimi, gospodarskimi in prostorskimi težavami. Mestne uprave zato izvajajo projekte prenove, $s$ katerimi želijo oživiti in obnoviti objekte, območjem povrniti družbenogospodarsko zmogljivost in izboljšati kakovost življenja njihovih prebivalcev. Neupoštevanje kompleksnosti prostorskih posegov v stare mestne predele pa ima lahko neželene posledice, kot je dodatno poslabšanje kakovosti življenja. Avtorja v članku na primeru iranskega mesta Mašad proučujeta kakovost življenja v soseskah, vključenih v projekte prenove, pri čemer uporabljata kombinacijo kvantitativnih in kvalita- tivnih metod, vključno z vprašalniki, polstrukturiranimi intervjuji, georeferenciranimi podatki in neposrednim opazovanjem. Izsledki kažejo, da ima pomanjkanje trajnostnega financiranja projekta prenove okrožja Samen neželene prostorske, družbeno-kulturne in gospodarske vplive na staro jedro mesta Mašad ter občutno zmanjšuje kakovost življenja tamkajšnjih prebivalcev na račun zadovoljevanja interesov turistov, romarjev in zlasti zasebnih investitorjev.

Ključne besede: kakovost življenja, urbana preobrazba, urbana prenova, propadanje mestnih predelov, Iran 


\section{Uvod}

Tradicionalni razvoj mest se $\mathrm{v}$ zadnjih letih spopada $s$ kompleksnimi izzivi, od krčenja mest do propadanja mestnih predelov ter težav, povezanih z upravljanjem okoljskih tveganj, ohranjanjem dediščine, varnostjo, prometom, zdravjem in družbeno neenakostjo (El Din idr., 2013; Marra idr., 2016). Propadanje mestnih predelov je eden najbolj perečih izzivov v razvoju mest, pri čemer nekdaj delujoče mesto ali njegov del začne propadati in se spopada z resnimi težavami, kot so upad prebivalstva, zapuščene stavbe in infrastruktura, visoka stopnja brezposelnosti, revščina, opustela mestna krajina, kriminal, nizek življenjski standard in slaba kakovost življenja (Dale, 1999; Deng in Ma, 2015; Andersen, 2019). Navedeno je zlasti značilno za nenačrtovana tradicionalna središča mest $\mathrm{v}$ državah $\mathrm{v}$ razvoju, kjer so ta središča običajno tudi najstarejši del mest (Ibem, 2013). V mestnem razvoju so stara mestna jedra običajno zapostavljena in se spopadajo $s$ težava$\mathrm{mi}$, povezanimi s propadanjem stavb, slabenjem gospodarske funkcije in izseljevanjem prebivalcev na boljša in sodobnejša območja (Munoth idr., 2013). S propadanjem stara mestna območja ne morejo več učinkovito zadovoljevati potreb prebivalcev, mestu pa lahko povzročajo težave na družbenem, kulturnem in gospodarskem področju (Dale, 1999).

Izkušnje po svetu kažejo, da lahko naložbe v stara mestna jedra pospešijo urbano revitalizacijo in razvoj turizma, ustvarijo nova delovna mesta, prekinejo izčrpavanje javnega proračuna, izboljšajo privlačnost za bivanje in socialno kohezijo ter zmanjšajo kriminal (Bigio in Licciardi, 2010). Mestne uprave zato rade posegajo v stara mestna jedra v okviru projektov urbane prenove, revitalizacije in preobrazbe (Bianchini in Parkinson, 1994; Leary in McCarthy, 2013). Namen obsežnih posegov je običajno zaustaviti propadanje z izboljšanjem prostorske zgradbe, družbene vključenosti, socialnih storitev in zlasti gospodarstva posameznih območij (Leary in McCarthy, 2013; Roberts idr., 2016). Ob upoštevanju načel spodbujanja participacije, krepitve pripadnosti skupnosti, izboljšanja enakopravnosti in okolja ter oživljanja gospodarstva ( $\mathrm{Ng}, 2005$; von Hoffman, 2008; McCormick idr., 2013) je lahko mestna prenova učinkovit način za krepitev trajnostne preobrazbe mest in izboljšanje kakovosti življenja na mikro- in makroravni. Navedeno se lahko doseže na podlagi številnih mehanizmov upravljanja, ki izhajajo iz dveh dokaj različnih usmeritev: tradicije univerzalizma in neoliberalističnega pogleda na urbana vprašanja (McCarthy, 2007; Leary in McCarthy, 2013). Pomanjkanje celostnega pristopa pri izvajanju tovrstnih projektov prenove pa lahko negativno vpliva na kakovost življenja prebivalcev, saj lahko povzroči netrajnostne spremembe, kot so zvišanje cen nepremičnin in življenjskih stroškov, družbena izključenost, gentrifikacija in razselitev prebivalcev z nižjim družbenoekonomskim položajem (Atkinson, 2000; Bacqué idr., 2011).

V zadnjih desetletjih je bilo razmerje med kakovostjo življenja in raznimi značilnostmi mest, kot so družbenoekonomski položaj prebivalcev (Mielck idr., 2014; Rokicka in Petelewicz, 2014; Bielderman idr., 2015), okoljski dejavniki (Lo in Faber, 1997; Li in Weng, 2007), gostota prebivalstva (Cramer idr., 2004), gostota gospodinjstev (Carnahan idr., 1974) ter javne dobrine in gospodarska uspešnost (Deller idr., 2001), predmet številnih raziskav, kakovost življenja v stanovanjskih soseskah med izvajanjem projektov prenove pa je bila le redko proučevana, še zlasti na lokalni ravni. Ker lahko projekti prenove močno vplivajo na različne spremenljivke kakovosti življenja, kot so dejavniki prebivalstva, infrastrukture in okolja (Johansson, 2002; Li in Weng 2007; Lee, 2008), lahko proučevanje kakovosti življenja $\mathrm{v}$ soseskah, ki se preobražajo $\mathrm{v}$ okviru projektov prenove, prinese svež pogled na obravnavano tematiko.

V starem jedru iranskega mesta Mašad zadnjih 25 let poteka najdaljši in najobsežnejši vladni projekt prenove. Glavni cilj projekta prenove okrožja Samen je izboljšati kakovost življenja prebivalcev ter povečati uspešnost in konkurenčnost turizma v središču mesta na podlagi obsežnih prostorskih posegov. Tovrstni posegi v zgodovinsko mestno jedro imajo lahko najrazličnejše vplive in posledice, med katerimi je med najpomembnejšimi tudi spremenjena kakovost življenja. Avtorja se v članku osredotočata na staro jedro Mašada, ki je idealno za proučevanje kakovosti življenja $\mathrm{v}$ soseskah, ki se preobražajo v sklopu obsežnih projektov prenove.

\section{Metode}

Ker imajo lahko projekti prenove različne kvantitativne in kvalitativne vplive, je za proučevanje teh vplivov potrebna kombinacija kvantitativnih in kvalitativnih metod. Raziskava je zato potekala v dveh fazah, pri čemer so bili v prvi fazi zbrani in analizirani kvantitativni podatki, v drugi pa kvalitativni. Navedena mešana metoda se uporablja za razlago in interpretacijo kvantitativnih rezultatov na podlagi kvalitativnih podatkov in njihove analize (Creswell, 1999). Avtorja sta uporabila omenjeno mešano metodo ocenjevanja vplivov ob hkratnem upoštevanju načel participativnega vrednotenja (Roche, 1999; Morris idr., 2011; Catley idr., 2014; Forouhar, 2016).

Da bi proučila kakovost življenja $\mathrm{v}$ starem jedru Mašada ter vplive in posledice projekta prenove okrožja Samen, sta se avtorja oprla na konceptualni model kakovosti življenja (Slika 1), ki sta ga povzela iz literature (Day, 1987; Cummins, 1996; Musschenga, 1997; Seik, 2001; Johansson, 2002; 


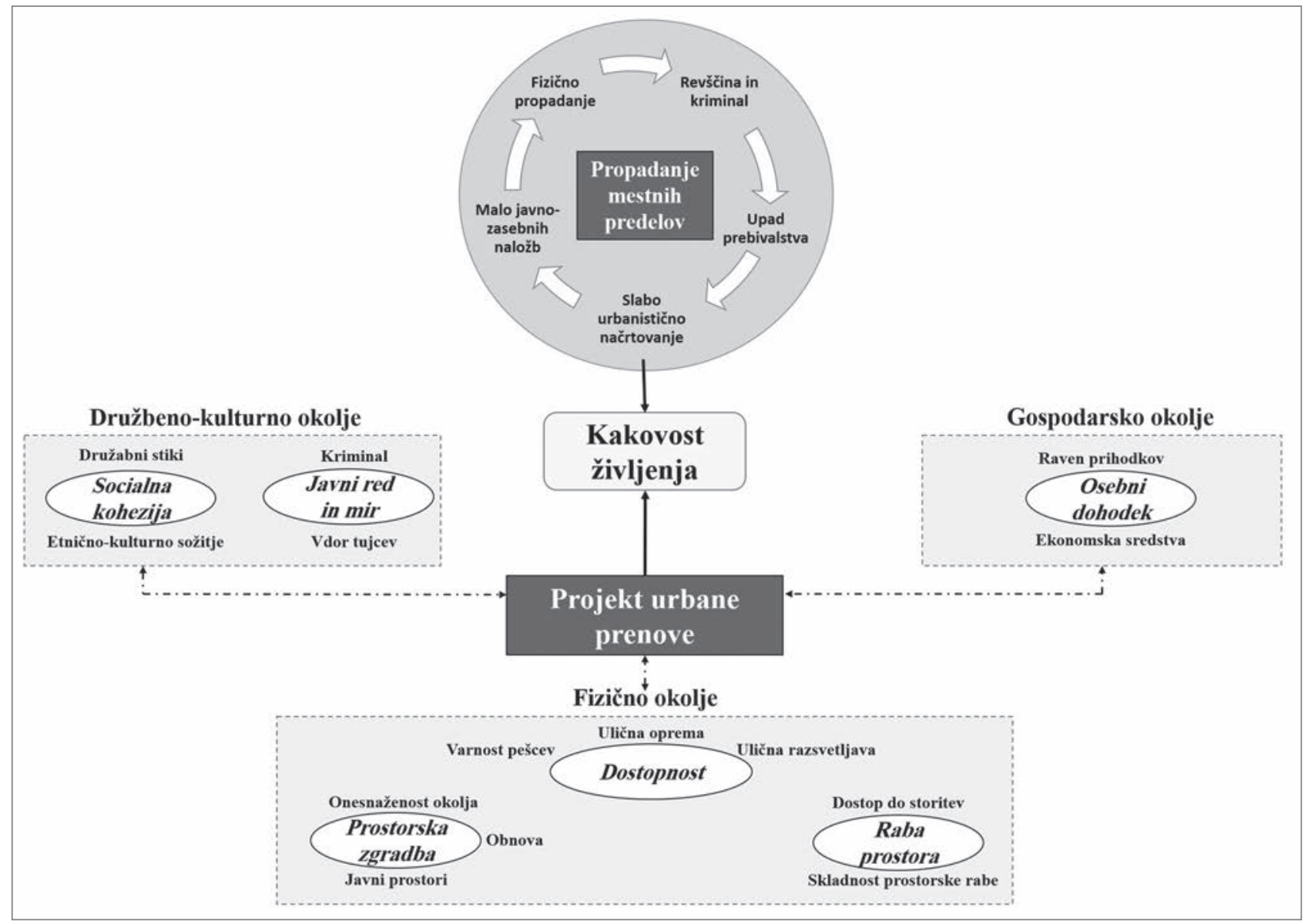

Slika 1: Konceptualni model kakovosti življenja (ilustracija: Amir Forouhar)

Costanza idr., 2007; Marans in Stimson, 2011). V skladu s tem modelom je propadanje mestnih predelov sociološki proces, za katerega so značilni neustrezna urbanistična politika, gospodarska stagnacija, zapuščene stavbe in infrastruktura, visoka stopnja brezposelnosti, revščina, kriminal, upadanje prebivalstva, nizek življenjski standard in slaba kakovost življenja (Dale, 1999; Deng in Ma, 2015; Andersen, 2019). Projekti prenove običajno poskušajo ustaviti propadanje z izboljšanjem prostorske zgradbe, družbeno-kulturnega okolja in zlasti gospodarstva posameznih območij. Kolikšen je poudarek na družbenem, gospodarskem in okoljskem vidiku, je odvisno od posameznega primera (Ibem, 2013; Leary in McCarthy, 2013; Tallon, 2013; Roberts idr., 2016; Andersen, 2019).

Avtorja sta v raziskavi uporabila vprašalnike, polstrukturirane intervjuje, georeferencirane podatke in metodo neposrednega opazovanja. Velikost vzorca za vprašalnike sta določila $\mathrm{z}$ uporabo programa IBM SPSS Sample Power 3.0.1, v katerem sta za merila izbrala največ 5 -odstotno verjetnost napake prve vrste, največ 20 -odstotno verjetnost napake druge vrste (ob najmanj 80-odstotni moči testa) in najmanjšo velikost učinka 0,2 . Na podlagi navedenih meril je bila izračunana velikost vzorca $265 . \mathrm{V}$ polstrukturirane osebne intervjuje je bilo na podlagi teoretične zasičenosti vključenih 35 prebivalcev proučevanega območja, 20 lastnikov trgovin, 10 turistov in 5 predstavnikov nepremičninskih agencij. Uporabljeno je bilo naključno vzorčenje z metodo sprehoda, pri kateri se število korakov med vzorčnimi točkami določi na podlagi naključnih števil, običajno vzetih iz tabel naključnih števil, pravokotni zavoj iz vsake vzorčne točke pa določi smer naslednje točke (Roche, 1999; Forouhar in Hasankhani, 2018).

Namen vprašalnikov in osebnih intervjujev je bil ugotoviti, kako zadovoljni so prebivalci s prostorskimi, družbeno-kulturnimi in gospodarskimi razmerami v svojem bivalnem okolju ter kako dojemajo spremembe v soseski in njihove vzroke. $\mathrm{V}$ okviru metod participativnega vrednotenja, kot so analiza trendov in zgodovinske časovnice (Roche, 1999; Morris idr., 2011; Catley idr., 2014; Forouhar, 2016), so bili anketiranci pozvani, naj opišejo potek nekaterih glavnih dogodkov v svojih soseskah skozi čas in se spomnijo, kaj je bil vzrok zanje; tako so lahko z logičnim dodajanjem drugih dogodkov in procesov izvajanja projekta prenove okrožja Samen rekonstruirali zgodovino. Za analizo kvalitativnih podatkov (tj. vseh posnetih intervjujev) je bil uporabljen sistem odprtega kodiranja, pri čemer so bili izbrani koncepti in oblikovane kategorije glede na informacije, pridobljene z intervjuji. 


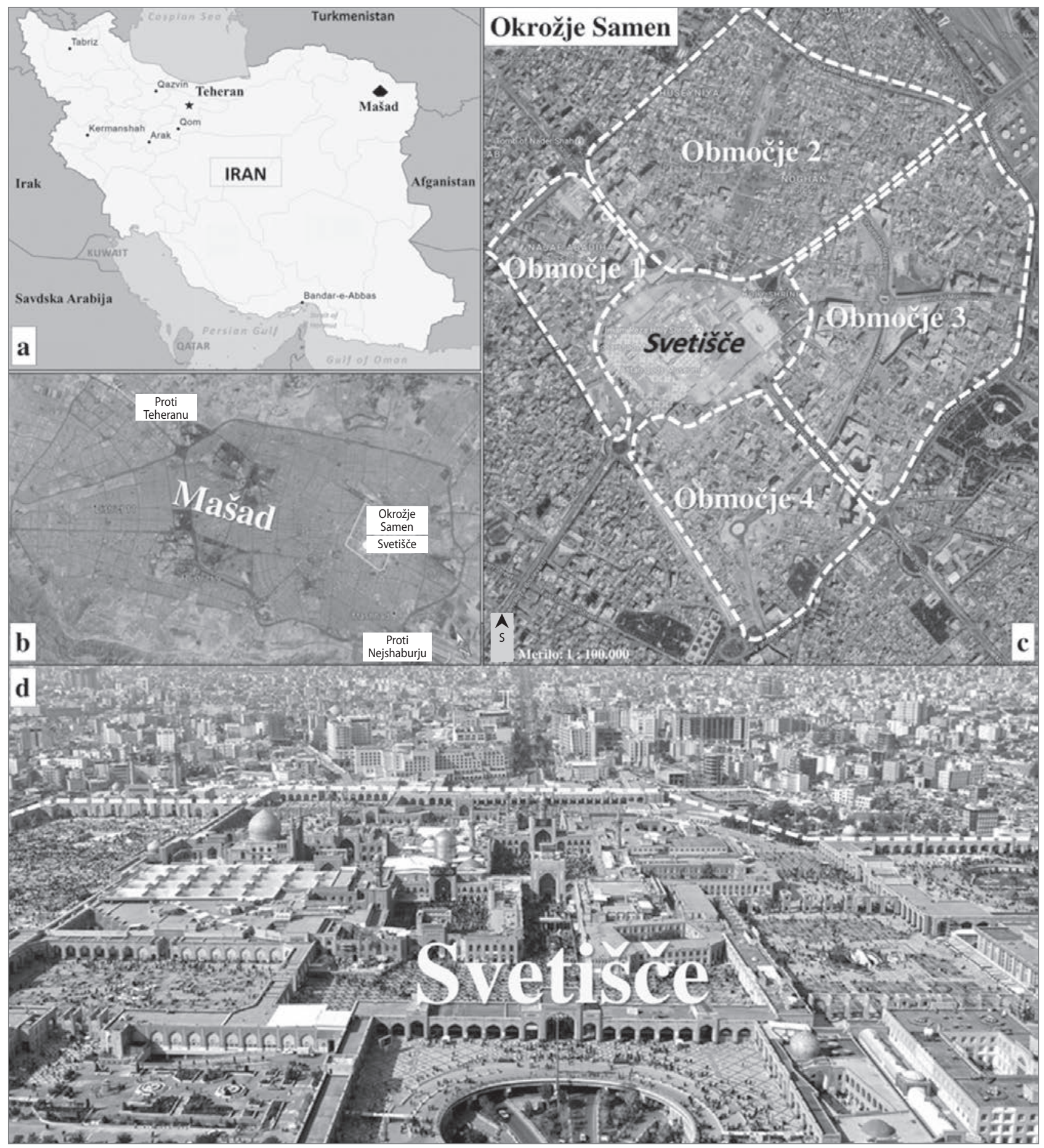

Slika 2: a) lokacija Mašada v Iranu (ilustracija: avtorja), b) Mašad, c) okrožje Samen z označenim območjem raziskave (oboje Map data, 2020), d) svetišče (foto: Mohammad Khoshneshin, ILNA News Agency)

\section{3 Študija primera}

Mašad je drugo največje iransko mesto in drugo največje šiitsko sveto mesto na svetu. Vsako leto ga obišče več kot 30 milijonov turistov in romarjev, med katerimi se pridejo mnogi poklonit v svetišče imama Reze, osmega šiitskega imama (Mashhad Municipality, 2017). Mesto je že od srednjega veka izjemno privlačno za romarje in turiste (Kafashpor idr., 2018). Po britansko-sovjetski invaziji na Iran leta 1941 je zaradi razmeroma negotovih razmer na podeželskih območjih prebivalstvo v Mašadu začelo naraščati. $V$ naslednjih letih se je hitra rast prebivalstva nadaljevala predvsem zaradi večjih državnih prihodkov od prodaje nafte, zatona fevdalnega družbenega reda, agrarne reforme, verskih znamenitosti in razvoja zdravstvenega sistema (Kheyroddin idr., 2014; Abrahamian, 2018; Rabbani idr., 2018). 
Preglednica 1: Zadovoljstvo prebivalcev z bivalnim okoljem

\begin{tabular}{|c|c|c|c|c|c|c|c|}
\hline \multirow[t]{2}{*}{ Prvina } & \multirow[t]{2}{*}{ Vidik } & \multirow[t]{2}{*}{ Kazalnik } & \multicolumn{5}{|c|}{ Zadovoljstvo (v \%) } \\
\hline & & & 1 & 2 & 3 & 4 & 5 \\
\hline \multirow[t]{8}{*}{ Fizično okolje } & Dostopnost & Ulična razsvetljava & 35,1 & 31,3 & 28,1 & 3,7 & 1,8 \\
\hline & & Ulična oprema & 31,3 & 38,2 & 21,8 & 5,8 & 2,9 \\
\hline & & Varnost pešcev & 26,4 & 37,5 & 26,3 & 6.1 & 3,7 \\
\hline & Prostorska zgradba & Obnova & 30,5 & 39,3 & 21,9 & 7,2 & 1,1 \\
\hline & & Javni prostori & 38,2 & 34,2 & 20,1 & 5,2 & 2,3 \\
\hline & & Onesnaženost okolja & 28,7 & 43,3 & 24,0 & 4,0 & 0,0 \\
\hline & Raba prostora & Dostop do storitev & 29,3 & 40,0 & 26,0 & 4,0 & 0,7 \\
\hline & & Skladnost prostorske rabe & 22,9 & 51,1 & 19,0 & 4,0 & 3,0 \\
\hline \multirow[t]{4}{*}{$\begin{array}{l}\text { Družbeno-kulturno } \\
\text { okolje }\end{array}$} & Javni red in mir & Kriminal & 38,0 & 41,3 & 16,7 & 4,0 & 0,0 \\
\hline & & Vdor tujcev & 32,4 & 41,5 & 21,3 & 4,7 & 0,1 \\
\hline & Socialna kohezija & Družabni stiki & 15,4 & 36,2 & 36,7 & 8,7 & 3,0 \\
\hline & & Etnično-kulturno sožitje & 24,9 & 33,2 & 29,3 & 9,2 & 3,4 \\
\hline \multirow[t]{2}{*}{ Gospodarsko okolje } & Osebni dohodek & Raven prihodkov & 47,3 & 34,7 & 14,7 & 3,3 & 0,0 \\
\hline & & Ekonomska sredstva & 41,3 & 37,2 & 17,2 & 2,5 & 1,8 \\
\hline
\end{tabular}

Legenda: 1 = zelo nezadovoljen, 2 = nezadovoljen, 3 = niti zadovoljen niti nezadovoljen, 4 = zadovoljen, 5 = zelo zadovoljen

Preglednica 2: Opisna statistika kakovosti življenja na proučevanem območju

\begin{tabular}{llllllllllll}
\hline \multicolumn{10}{c}{ Opisna statistika } \\
\hline & Povprečje & $\begin{array}{l}\text { Spodnja } \\
\text { meja }\end{array}$ & $\begin{array}{l}\text { Zgornja } \\
\text { meja }\end{array}$ & Mediana & Modus & Varianca & $\begin{array}{l}\text { Standardni } \\
\text { odklon }\end{array}$ & Min. & Maks. & Razpon \\
\hline Skupaj & 3,2100 & 2,8866 & 3,5182 & 3,0000 & 2,00 & 3,567 & 1,83014 & 1,00 & 9,00 & 8,00 \\
\hline Moški & 4,1432 & 3,6581 & 4,3648 & 4,0000 & 3,00 & 3,003 & 1,67712 & 2,00 & 9,00 & 7,00 \\
\hline Ženske & 2,2768 & 2,0148 & 2,7400 & 2,0000 & 2,00 & 2,651 & 1,57602 & 1,00 & 8,00 & 7,00 \\
\hline
\end{tabular}

Preglednica 3: $t$-test za en vzorec

\begin{tabular}{llllll}
\hline \multicolumn{5}{l}{ Statistika $t$-testa } \\
\hline$t$ & $d f$ & Stat. znač. (dvostranski test) & Razlika od hip. povpr. & Spodnja meja & Zgornja meja \\
\hline-12.670 & 146 & .000 & -2.19000 & -2.5132 & -1.8868 \\
\hline
\end{tabular}

V zadnjih desetletjih je bilo središče Mašada, ki vključuje tudi staro mestno jedro v okolici svetišča (okrožje Samen), v mestnem razvoju potisnjeno na rob, pri čemer se je spopadalo z resnimi težavami, povezanimi s propadanjem objektov in njihovih funkcij. Leta 1965 je vlada dala pobudo za pomemben projekt prenove okolice svetišča, pri katerem bi se zamenjale razpadajoče stavbe in infrastruktura. Čeprav je bil projekt leta 1968 uradno potrjen in so bile nekatere soseske porušene, so ga po iranski revoluciji leta 1978 opustili (Sarkheyli idr., 2016; Kafashpor idr., 2018; Forouhar in Forouhar, 2020). Zaradi pomembnosti svetišča in njegovega turističnega potenciala ter čedalje večjih družbeno-kulturnih, gospodarskih in političnih težav, s katerimi se je spopadalo staro mestno jedro, je vlada leta 1992 začela izvajati megaprojekt prenove okrožja Samen. Njegov glavni cilj je izboljšati kakovost življenja prebivalcev, zadovoljiti potrebe turistov in romarjev, izboljšati urbane storitve ter okrepiti gospodarsko uspešnost in konkurenčnost mestnega jedra na regionalni in svetovni ravni (Hosseyni, 2008; Sarkheyli idr., 2016). Projekt prenove okrožja Samen je danes največji in najdlje trajajoč projekt prenove v Iranu. Obsega približno 366 ha, vodi pa ga Organizacija za obnovo okrožja Samen (Slika 2). Ker je v 25 letih dosegel samo $50 \%$ zastavljenih ciljev, se je spremenil v enega najspornejših megaprojektov v Iranu, ki povzroča resne težave pri upravljanju mesta.

\section{Rezultati}

Skupno je anketo izpolnilo 140 moških (52,8 \%) in 125 žensk (47,2\%; količnik: 1,12$)$. Njihova povprečna starost je bila 34 let (v razponu od 15 do 78 let). $49 \%$ anketirancev se je na proučevano območje priselilo, kar kaže, da je zanj značilna visoka stopnja priseljevanja. Poleg tega jih je 37,3\% tam živelo manj kot pet, 69,1\% pa manj kot deset let, kar pomeni, da 
Preglednica 4: Korelacije med prvinami/vidiki in kakovostjo življenja na proučevanem območju

\begin{tabular}{lll}
\hline & Kakovost življenja & \\
\hline Fizično okolje & Pearsonov koeficient & Stat. znač. (dvostranski test) \\
\hline Dostopnost & $0,755^{*}$ &, 000 \\
\hline Prostorska zgradba & $0,696^{*}$ &, 000 \\
\hline Raba prostora & $0,719^{*}$ &, 000 \\
\hline Družbeno-kulturno okolje & $0,657^{*}$ &, 000 \\
\hline Javni red in mir & $0,751^{*}$ &, 000 \\
\hline Socialna kohezija & $0,746^{*}$ &, 000 \\
\hline Gospodarsko okolje & $0,625^{*}$ &, 000 \\
\hline Osebni dohodek & $0,624^{*}$ &, 000 \\
\hline
\end{tabular}

Opomba: ${ }^{*} p=, 01$.

se starejši prebivalci iz soseske odseljujejo. V preglednici 1 so navedeni podatki o zadovoljstvu lokalnih prebivalcev s prostorskimi, družbeno-kulturnimi in gospodarskimi razmerami v njihovem bivalnem okolju.

Iz Preglednic 2 in 3 je razvidno, da so v povprečju anketiranci kakovost svojega življenja ovrednotili z oceno 3,21 na lestvici od 1 do 10, kar je nižje od hipotetičnega povprečja $(5,50)$. Primerjava med spoloma razkrije, da so v povprečju ženske kakovost svojega življenja ocenile slabšse kot moški. Poleg tega so rezultati $t$-testa za en vzorec pokazali, da je kakovost življenja v statistični populaciji slabša od hipotetičnega povprečja (interval zaupanja: $99 \%$ ). Pearsonov koeficient korelacije kaže, da je med vsemi proučevanimi prvinami fizično okolje najmočneje povezano s subjektivno kakovostjo življenja. Bolj zadovoljni ko so z njim prebivalci, večja je njihova kakovost življenja in obratno. Med proučevanimi vidiki posameznih prvin pa je s kakovostjo življenja najmočneje povezan javni red in mir (Preglednica 4).

\subsection{Prostorski vplivi}

Eden glavnih ciljev projekta prenove okrožja Samen je bil prebivalcem in romarjem zagotoviti dostop do trgovin, rekreacijskih in nastanitvenih objektov ter svetišča po celotnem zgodovinskem jedru Mašada. Glavni poudarek je bil na gradnji dveh avenij in več servisnih cest okrog novih poslovno-trgovskih stavb in hotelov (Samen Renewal Organization, 2002). Zaradi omenjene gradnje so bile v okrožju uničene številne starejše ceste, zaradi česar morajo prebivalci in romarji že dve desetletji uporabljati druge ali začasne poti. Več kot $65 \%$ anketirancev je bilo nezadovoljnih ali zelo nezadovoljnih z razsvetljavo pločnikov in drugih površin za pešce. Samo 2,9 \% jih je bilo zelo zadovoljnih z ulično opremo, več kot dve tretjini pa jih je bilo (zelo) nezadovoljnih z varnostjo pešcev.
Terenska raziskava je pokazala, da so samo servisne ceste do novih poslovno-trgovskih stavb in nastanitvenih objektov (nakupovalnih središč, luksuznih hotelov in drugih oblik nastanitve) dobro zasnovane ter imajo primerno razsvetljavo in ulično opremo. Začasne ceste, večino katerih uporabljajo tudi pešci, niso primerno osvetljene ali prilagojene ranljivim skupinam ter nimajo dobro zasnovane in skladne ulične opreme (Slika 3). Poleg tega na njih ni poskrbljeno za varnost pešcev v prometu. Organizacija za obnovo okrožja Samen daje prednost dostopu do dobičkonosnih poslovno-trgovskih in hotelskih kompleksov, zanemarja pa potrebe po izboljšanju začasnih lokalnih cest, ker je to predrago. »Projekt prenove prebivalcem te soseske ni prinesel drugega kot razdejanje. Mnoge lokalne ulice so bile uničene, da so lahko zagotovili dostop do nakupovalnih središč, hotelov in hostlov, mestne oblasti pa so uredile začasne poti za pešce, po katerih je ponoči težko hoditi, tudi če imaš žepno svetilko.« (38-letni prebivalec območja)

Projekt prenove okrožja Samen naj bi izboljšal kakovost okolja s stalnim obnavljanjem, izboljšanjem opremljenosti javnih prostorov in zmanjšanjem onesnaženosti okolja. Več kot $60 \%$ anketirancev je bilo nezadovoljnih ali zelo nezadovoljnih z doseženimi rezultati. Med letoma 2013 in 2015 je bilo število gradbenih dovoljenj, izdanih v okrožju Samen, zelo nizko v primerjavi s številom dovoljenj, izdanih v celotnem mestu: 60 jih je bilo izdanih leta 2013 (0,8\% vseh izdanih dovoljenj), 19 leta $2014(0,03 \%)$ in 19 leta 2015 (0,5\%; Samen Renewal Organization, 2002). Čeprav je bilo izdano zanemarljivo število dovoljenj, ta pokrivajo velika območja; v povprečju so dovoljenja leta 2013 pokrivala površino $8.640 \mathrm{~m}^{2}$, leta $20144.156 \mathrm{~m}^{2}$ in leta $20156.039 \mathrm{~m}^{2}$. Statistični podatki kažejo, da so bila gradbena dovoljenja izdana za obsežne poslovno-trgovske gradbene projekte, ne za objekte lokalnih prebivalcev. Glavni cilj je komercializacija stanovanjskih območij v okolici svetišča s poudarkom na ustvarjanju dobička, ne na izboljšanju kakovo- 


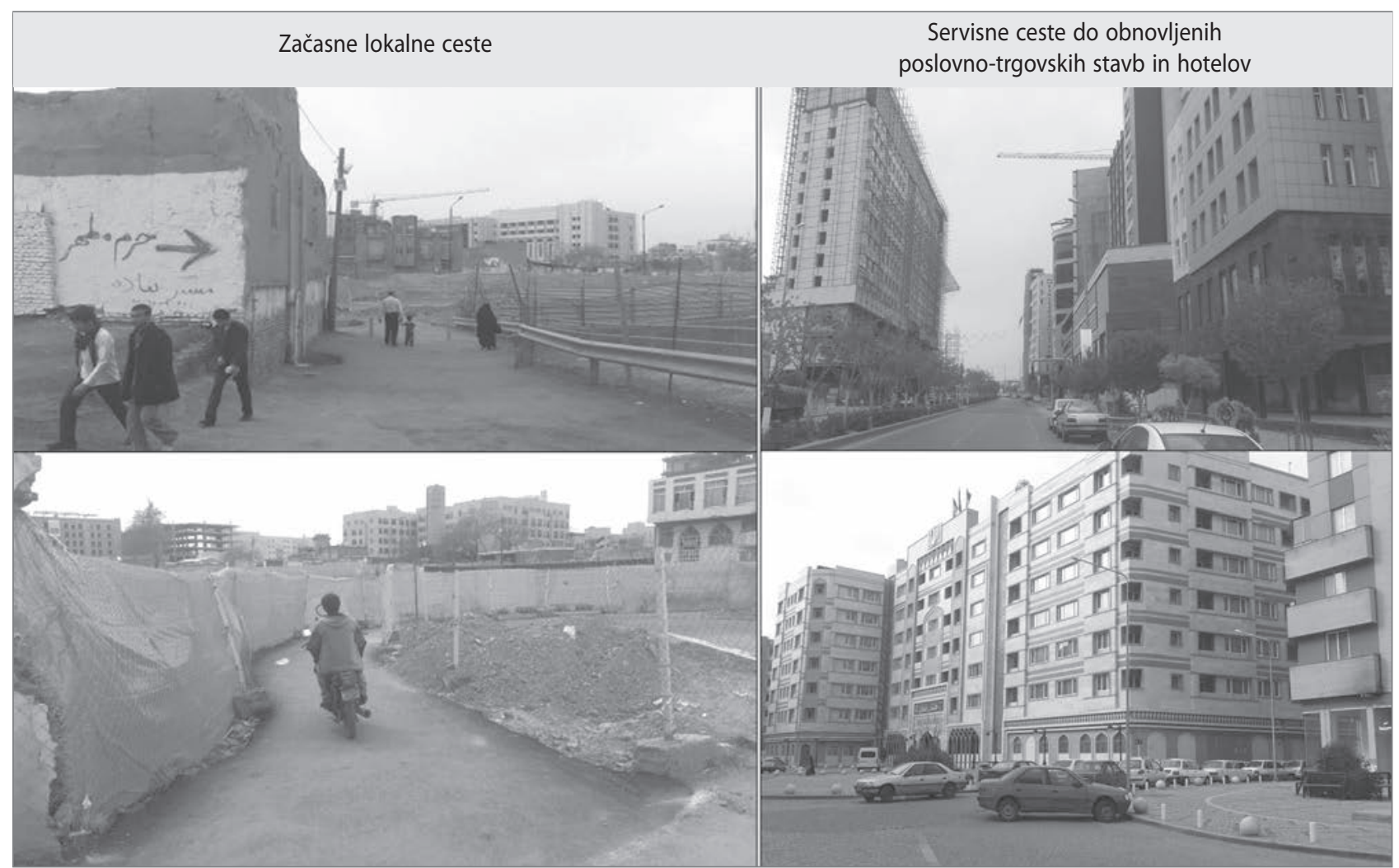

Slika 3: Primerjava začasnih lokalnih cest in servisnih cest do novih poslovno-trgovskih stavb in hotelov (foto: Navid Forouhar)

sti življenja prebivalcev. Intervjuji s predstavniki nepremičninskih agencij razkrivajo še, da je izvajanje projekta pomembno vplivalo na upad izvajanja obnov manjšega obsega med prebivalci. Takoj po začetku projekta je Organizacija za obnovo okrožja Samen začasno prekinila izdajanje gradbenih dovoljenj in prebivalcem prepovedala prodajo nepremičnin, zaradi česar sta se zasebna gradnja in obnova takoj zaustavili. Prebivalci so lahko svoje nepremičnine prodali samo navedeni organizaciji, seveda po nizki ceni, ali pa prodajo prestavili za nedoločen čas (City Council of Mashhad, 2016).

Terenska raziskava je pokazala, da se nekateri prazni prostori, ki so ostali po rušitvi starih stavb, trenutno uporabljajo kot parkirišča, nekateri pa so se spremenili v nevarna območja, ki se jim je bolje izogniti. Glavni razlog, ki je upravičeval izvedbo projekta prenove, so bile slabe sanitarno-higienske razmere (Samen Renewal Organization, 2002), vendar so intervjuji in terenske raziskave razkrili, da se je okoljska onesnaženost zdaj še bolj povečala, saj so se porušene stavbe spremenile v odlagališča gospodinjskih in gradbenih odpadkov. Leta 2016 je bilo po podatkih mestne zdravstvene organizacije v okrožju Samen največ primerov okužb s kožno lišmeniazo. Dolgotrajna gradnja poslovno-trgovskih stavb, hotelov in cest poleg tega povzroča nezaželen hrup, ki lahko negativno vpliva na telesno in psihično zdravje prebivalcev ter posledično poveča verjetnost za nastanek raznih bolezni.

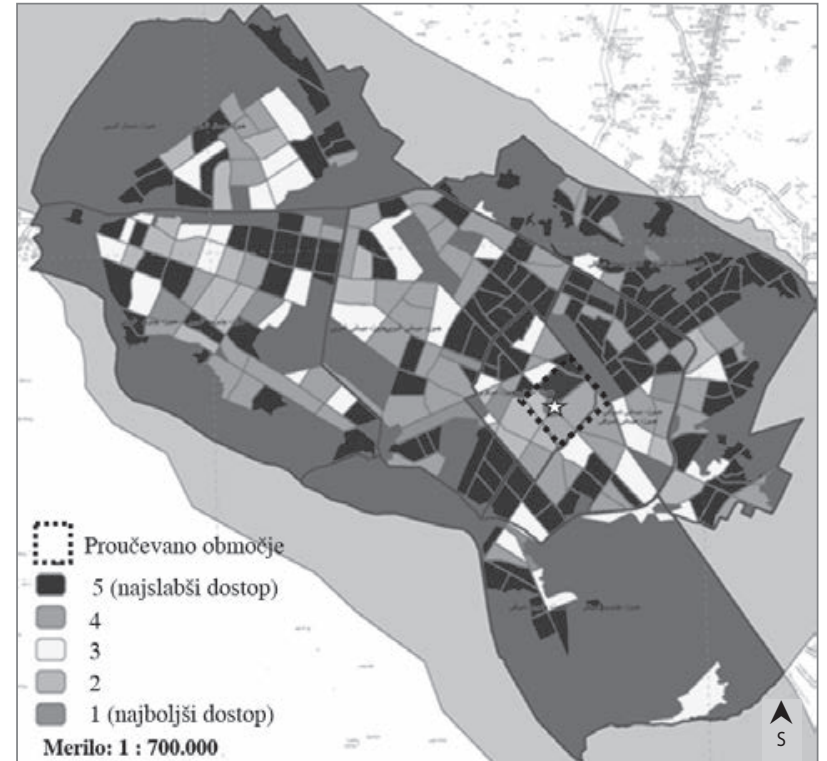

Slika 4: Dostop do storitev v Mašadu (ilustracija: Amir Forouhar; vir: Mashhad Municipality, 2017)

Izsledki anket kažejo, da projektu prenove ni uspelo obdržati ravnovesja med potrebami prebivalcev in romarjev. Skoraj dve tretjini anketirancev sta bili nezadovoljni ali zelo nezadovoljni z dostopom do storitev in s skladnostjo prostorske rabe. Leta 2008 so se oblasti odločile, da bodo k projektu pritegnile nove investitorje, ki bi financirali in pospešili njegovo izvedbo. 


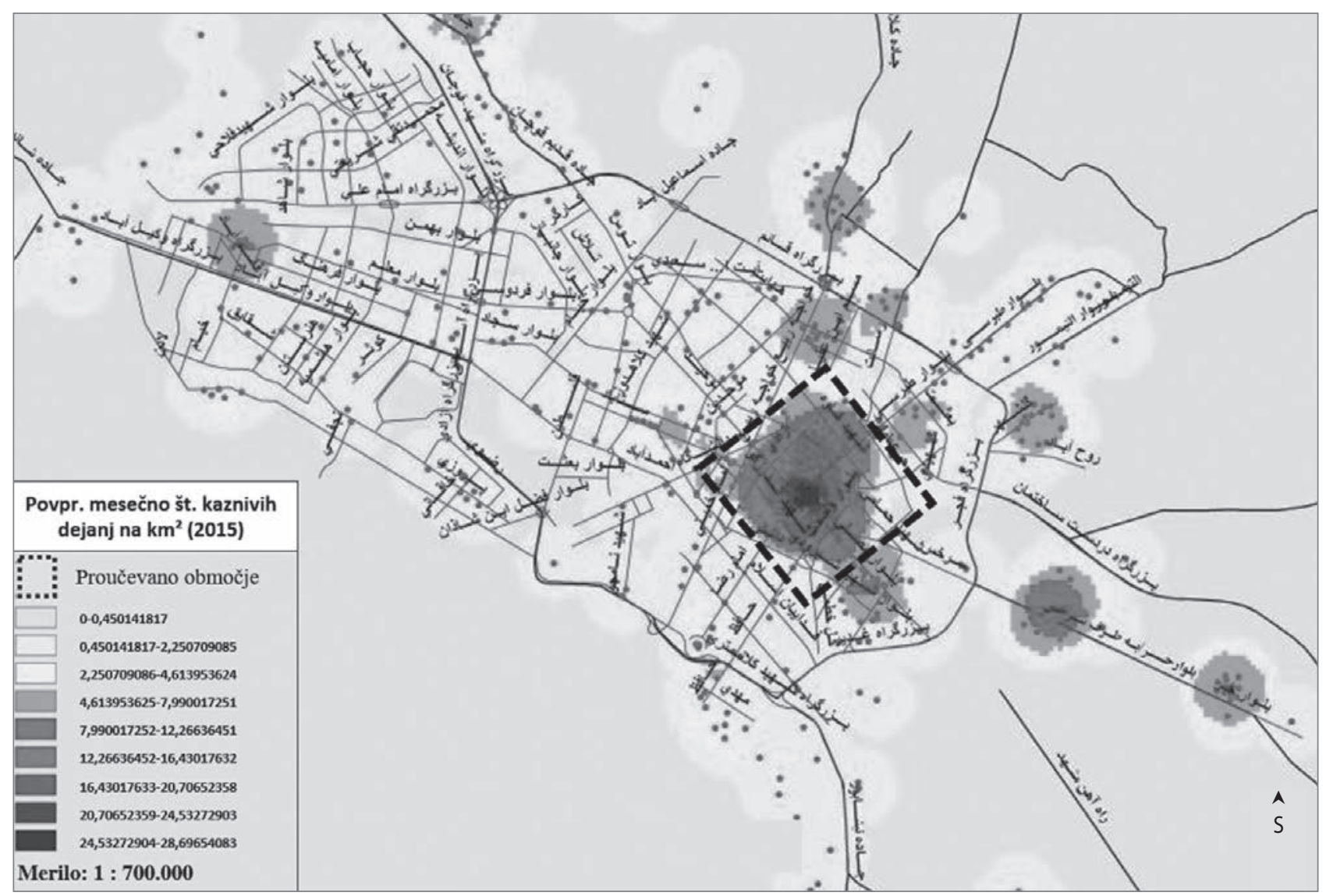

Slika 5: Stopnja kriminala v Mašadu (vir: Mashhad Police Department, 2016)

Organizacija za obnovo okrožja Samen je v prvotno predlagani načrt rabe prostora vnesla pomembne spremembe, na podlagi katerih so bile prvotno predvidene stanovanjske parcele spremenjene v velike poslovno-trgovske površine. Številne hiše so bile v skladu z zakonom kupljene po nizkih cenah, njihove parcele pa so bile nato združene $\mathrm{v}$ večja zemljišča, na katerih so zgradili poslovne stolpnice, nakupovalna središča in luksuzne hotele. Omenjena organizacija se je osredotočala na obsežne poslovno-trgovske gradbene projekte, namesto da bi zagotovila cenovno dostopna stanovanja, izobraževalne in zdravstvene storitve ali javne prostore. Na Sliki 4 je razvidno pomanjkanje storitev v okrožju Samen. Intervjuji z romarji so razkrili, da so veliki hoteli primerni samo za bogatejše romarje, zaradi njih pa imajo drugi romarji slabši dostop do cenovno ugodnejših storitev in nastanitvenih objektov. $\gg V$ preteklosti smo prenočevali v hišah lokalnih prebivalcev. Nastanitev ni bila visoke kakovosti, a cenovno zelo ugodna za revnejše romarje. Nato pa so te hiše porušli in zgradili luksuzne hotele, ki si jih večina romarjev ne more privoščiti.« (39-letni romar)

\subsection{Družbeno-kulturni vplivi}

Na kakovost življenja močno vpliva občutek anomije, ki je običajno tudi razlog za nezadovoljstvo z življenjem (Genov, 1998;
Western in Lanyon, 1999; Huschka in Mau, 2005). Kazniva dejanja, kot so prekupčevanje z mamili in alkoholom, izsiljevanje, nadlegovanje in prostitucija, lahko močno poslabšajo kakovost življenja v mestnih soseskah. Zaradi vdora tujcev v neustrezno zavarovane stanovanjske soseske se lahko poveča kriminal, kar lahko močno poslabša zadovoljstvo z življenjem tamkajšnjih stanovalcev (Huppert idr., 2009, Hanson idr., 2010; Kitchen in Williams, 2010). Skupno je bilo $77,3 \%$ anketirancev nezadovoljnih ali zelo nezadovoljnih $s$ stopnjo kriminala v svojih soseskah, $73,9 \%$ pa jih je bilo nezadovoljnih ali zelo nezadovoljnih z vdorom neznanih ljudi v njihov življenjski prostor. Po podatkih poročila o preprečevanju kaznivih dejanj in varnosti v lokalnih skupnostih v Mašadu za leto 2016 so glavna žarišča kriminala prav v okrožju Samen (Slika 5). Pregled števila oseb, ki prestajajo kazen v osrednjem mestnem zaporu, kaže, da je okrožje Samen na prvem mestu po številu kaznivih dejanj zoper javni red in mir, goljufij in kaznivih dejanj zoper ljudi in premoženje. Poleg tega je okrožje na drugem mestu po številu drugih kaznivih dejanj, kot so zloraba mamil, prekupčevanje z mamili in tatvine (Mashhad Police Department, 2016). K porastu kriminala v okrožju so poleg neugodnih družbenogospodarskih razmer pripomogli tudi slabo prostorsko načrtovanje, zaradi česar so nekatera območja postala nevarna (vogali in območja v obliki črke $\mathrm{L}$ in $\mathrm{U}$ ), in zapuščena zemljišča, ki so posledica obsežnega rušenja med projektom prenove. Intervju- 


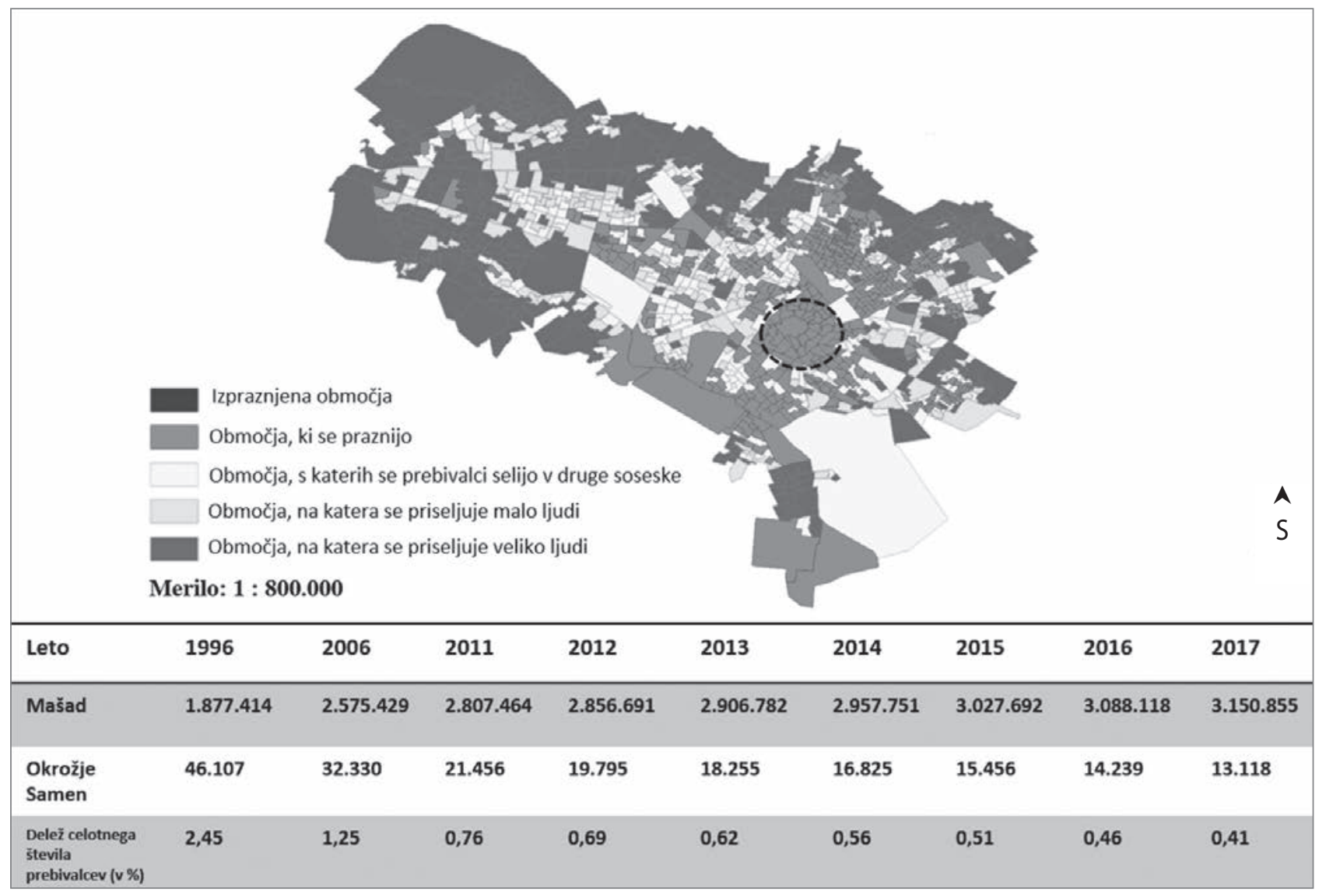

Slika 6: Spreminjanje prebivalstva v Mašadu (vir: Mashhad Municipality, 2017)

\subsection{Gospodarski vplivi}

ji so razkrili, da se je zaradi nenadzorovane rasti števila hotelov in hostlov, zgrajenih med prenovo, povečala tudi prisotnost tujcev v okrožju. Zaradi slabšanja kakovosti življenja v soseskah so stanovalci začeli zapuščati svoje hiše in jih nezakonito oddajati turistom in romarjem. Po uradnih statističnih podatkih se v okrožju trenutno 3.300 zasebnih hiš nezakonito oddaja romarjem (City Council of Mashhad, 2016).

V zadnjih dveh desetletjih v okrožju Samen število prebivalcev močno upada, trenutno velja za območje, ki se prazni (Slika 6). Po poročanju anketirancev so bili pred projektom prenove družabni stiki v okrožju živahnejši, sorodniki pa so običajno živeli v istih soseskah. Pa razselitvi nekdanjih prebivalcev so se tradicionalne družbene vezi v soseskah močno razrahljale. Zaradi slabe kakovosti okrožja se vanj pogosto naseljujejo revni migranti. Okrožje Samen je trenutno druga najbolj priljubljena destinacija za neiranske priseljence v Mašadu (City Council of Mashhad, 2016), zaradi česar se je etnično-kulturno sožitje stanovalcev močno poslabšalo. Več kot polovica anketirancev je bila nezadovoljna ali zelo nezadovoljna s kakovostjo družabnih stikov ter etnično-kulturnim sožitjem v svojih soseskah.
Osebni dohodek ima neposreden vpliv na subjektivno kakovost življenja, pomembno pa vpliva tudi na zmožnost prebivalcev, da sodelujejo pri obnovi (Ashley in Carney, 1999; Karl, 2000). Stopnja prihodkov prebivalcev okrožja Samen je neposredno povezana z njihovo zaposlitvijo in ekonomskimi sredstvi, kot so zemljiščca in nepremičnine (Saghatoleslami, 2017; Kafashpor idr., 2018). Čeprav je okrožje zaradi svetišča postalo eno najbolj dobičkonosnih turističnih območij v Iranu, je bilo manj kot $5 \%$ anketirancev zadovoljnih ali zelo zadovoljnih s svojimi prihodki in ekonomskimi sredstvi. Pred projektom prenove se je večina prebivalcev preživljala s turizmom, pri čemer so turistom prodajali razne izdelke, imeli so trgovine s spominki ali pa so romarjem in turistom oddajali hiše in stanovanja. Lokalno trgovino so močno prizadela velika nakupovalna središča, zgrajena med projektom prenove, zaradi prepovedi zasebne gradnje in obnove pa so prihodki prebivalcev od oddajanja hiš v najem močno upadli. Anketiranci so navedli, da jim je soseska nekoč zagotavljala vir prihodka, projekt prenove pa je močno prizadel njihove službe in zmanjšal njihove prihodke. »Po uvedbi projekta je bilo veliko stavb uničenih in zamenjanih s prestižnimi nakupovalnimi središči, ki so pritegnila večino naših strank. 
Nismo bili konkurenčni, zato smo izgubili stranke in ni nam preostalo drugega, kot da zapremo trgovino. « (31-letni lastnik trgovine)

Tudi intervjuji s predstavniki nepremičninskih agencij so razkrili, da se je zaradi projekta prenove zmanjšala vrednost nepremičnin v lasti prebivalcev. Nepremičnine so lahko prodali samo Organizaciji za obnovo okrožja Samen, pri čemer so se cene, ki jih je postavila organizacija, močno razlikovale od dejanske vrednosti nepremičnin na stanovanjskem trgu. Dolgotrajno izvajanje projekta je negativno vplivalo na vrednost lokalnih nepremičnin. »Svoje nepremičnine smo morali poceni prodati, drugače nam bi organizacija odklopila elektriko, plin in pitno vodo. Vrednost se je povečevala samo velikim poslovnim zemljiščem $v$ lasti investitorjev, ne pa tudi lokalnim nepremičninam.« (43-letna prebivalka)

\section{Razprava}

Propadanje mestnih predelov v Iranu ima več vzrokov. Je posledica različnih med seboj povezanih družbenogospodarskih razmer in urbanističnih politik v zadnjih desetletjih, med drugim tudi namenjanja nezadostne pozornosti dopolnilni gradnji in javno-zasebnim partnerstvom (Sarkheyli idr., 2016; Abrahamian, 2018). Čeprav naj bi obsežen projekt prenove okrožja Samen izboljšal kakovost življenja prebivalcev ter uspešnost in konkurenčnost turizma, ima neželene prostorske, družbeno-kulturne in gospodarske posledice.

Že od začetka obsežnega projekta prenove imata občina in Organizacija za obnovo okrožja Samen zaradi pomanjkanja stalnih finančnih sredstev resne težave z njegovim izvajanjem. Po finančnih sankcijah, uvedenih zoper Iran po vojni z Irakom leta 1979, je iranska vlada uvedla nov finančni sistem za občine (Sarkheyli idr., 2016; Gholizadeh in Aminirad, 2018). Nova zakonodaja je občinam prekinila dostop do večine državne pomoči, ki so jo do takrat prejemale, ne da bi pri tem določila kakršne koli nove finančne vire. V skladu z navedenim vlada projektu prenove okrožja Samen ni hotela dodeliti finančnih sredstev, zato je bila organizacija, ki je projekt vodila, prisiljena stvar financirati iz lastnih sredstev in na podlagi ničelnega predračunavanja. Podobno kot pri projektih urbane prenove na Tajvanu (Hsu in Chang, 2013), Kitajskem (Chen, 2013) in v Kanadi (Zuberi in Taylor, 2013) so se zaradi spremenjenega načina financiranja prvotni cilji projekta prilagodili ciljem zasebnih investitorjev. Kot navajajo Cullingworth idr. (2013), teh ne zanima gradnja stanovanj za ljudi z nizkimi prihodki (ne glede na to, ali so subvencionirana ali ne), temveč gradnja trgovsko-poslovnih središč. Zato sta občina in Organizacija za obnovo okrožja za glavni cilj projekta določili razvoj turizma, ki bi v središče Mašada pritegnil zasebne in druge investitorje.
Posledično je organizacija temeljito spremenila prvotni načrt rabe prostora, da bi upoštevala interese investitorjev in zagotovila sredstva za izvedbo projekta, pri čemer je povečala zlasti gostoto območij poslovno-trgovske dejavnosti.

Oblasti so poskušale pridobiti zemljišča in nepremičnine na podlagi odredb o prisilni prodaji. Podobno kot pri odmevnih projektih urbane prenove drugod po svetu - na primer pri prenovi londonskega pristanišča in sanaciji degradiranega industrijskega predela v Sheffieldu (Imrie in Thomas, 1997) - je bila odredba v okrožju Samen sprejeta s splošnim nasprotovanjem vseh tistih, ki so bili prisiljeni prodati svoja zemljišča. Podobno kot v več primerih v ZDA (Teaford, 2000) so bile skupine prebivalcev z nižjimi dohodki razlaščene in razseljene, njihova zemljišča in hiše pa so nadomestili prometna infrastruktura, nakupovalna središča, luksuzni stanovanjski bloki in hoteli. Nasprotovanje lokalnih prebivalcev in lastnikov trgovin je močno podaljšalo izvedbo projekta, ki je še po 25 letih le na pol dokončan.

Izsledki raziskave, predstavljene v članku, se ujemajo z ugotovitvami raziskav gentrifikacije in urbane prenove v Kanadi $(\mathrm{Zu}-$ beri in Taylor, 2013) in Turčiji (Güzey, 2013), kjer se zaradi neoliberalistične politike urbane prenove in čedalje večjega opiranja na zasebni sektor javno dobro in potrebe lokalnih prebivalcev čedalje manj upoštevajo, prednost pa se daje interesom zasebnih investitorjev. Uporabljeni kapitalistični pristop je socialne cilje in potrebe prebivalcev stanovanjskih sosesk $\mathrm{v}$ okolici svetišča potisnil v ozadje, hkrati pa je zaradi negativnih prostorskih, družbeno-kulturnih in gospodarskih posledic poslabšala kakovost njihovega življenja. Zaradi družbenih napetosti, ki so posledica stalnega razseljevanja in ekonomskih pritiskov, bodo urbanisti in oblikovalci politik, ki sodelujejo v projektu prenove okrožja Samen, še naprej težko ohranjali ravnovesje med potrebami prebivalcev, turistov in zasebnih investitorjev.

\section{Sklep}

Projekt prenove okrožja Samen je z uporabo neparticipativnega načrtovalskega in hkrati kapitalističnega pristopa posegel v fizični prostor stanovanjskih sosesk okoli svetišča imama Reze v osrednjem predelu Mašada. Izsledki raziskave kažejo, da ima poseg na omenjene soseske negativne prostorske, družbeno-kulturne in gospodarske vplive. $V$ povprečju je bilo $68 \%$ anketirancev iz okrožja Samen nezadovoljnih ali zelo nezadovoljnih z dostopnostjo, 71,4 \% s prostorsko zgradbo, 71,6 \% z rabo prostora, $75,6 \% \mathrm{z}$ javnim redom in mirom, $54,8 \% \mathrm{~s}$ socialno kohezijo in $80,2 \%$ z osebnim dohodkom. Neželene posledice izvajanja projekta prenove močno zmanjšujejo kakovost življenja na proučevanem območju. Anketiranci so na lestvici od 1 
do 10 kakovost življenja ocenili s 3,21. Poleg tega izsledki kažejo, da je prostorska ureditev sosesk najmočneje povezana $s$ subjektivno kakovostjo življenja v okrožju $(r=0,755)$.

Projekt prenove okrožja se je zaradi pomanjkanja trajnostnega financiranja močno oddaljil od prvotno zastavljenih ciljev in se preusmeril $\mathrm{k}$ interesom zasebnih in drugih investitorjev. Zaradi kapitalistične vizije so bile potrebe lokalnih prebivalcev zapostavljene na račun interesov turistov, romarjev in zlasti zasebnih investitorjev. Treba je poudariti, da trenutne razmere v okrožju Samen niso posledica samo nepravilne zasnove in izvedbe projekta, ampak so povezane tudi z iranskim naftnim gospodarstvom, $\mathrm{v}$ katerem priliv prihodkov od prodaje nafte povzroča rast cen nepremičnin in gentrifikacijo, zato nacionalna vlada in mestna uprava poskušajo zapolniti vrzel v prihodkih od najemnin in pridobiti čim večje finančne koristi iz projektov urbane prenove. Prihodnje raziskave bi se zato morale osredotočiti na dinamiko preobrazbe in gentrifikacije pri projektih urbane prenove v državah v razvoju (zlasti tistih, katerih gospodarstvo temelji na nafti), na podlagi njihovih izsledkov pa bi bilo treba oblikovati strategije in politike za ohranjanje ravnovesja med kakovostjo življenja prebivalcev, potrebami turistov in interesi investitorjev. Poleg tega bi si morali urbanisti in oblikovalci politik v prihodnje prizadevati za bolj raznovrstne, vključujoče in družbeno trajnostne projekte urbane prenove, treba pa bi bilo uvesti tudi nove mehanizme, ki bi zaustavili naraščajočo družbeno izključenost, gentrifikacijo in kratenje pravic med izvajanjem projektov.

Navid Forouhar, Islamic Azad University of Mashhad, School of Architecture and Art, Mashhad, Iran

E-naslov: navidforouhar@mshdiau.ac.ir

Amir Forouhar, Art University of Isfahan, Faculty of Architecture and Urban Planning, Isfahan, Iran

E-naslov: a.forouhar@aui.ac.ir

\section{Viri in literatura}

Abrahamian, E. (2018): A history of modern Iran. Cambridge, Cambridge University Press.

Andersen, H. S. (2019): Urban sores: On the interaction between segregation, urban decay and deprived neighbourhoods. London, Routledge. DOI: $10.4324 / 9781315191980$

Ashley, C., in Carney, D. (1999): Sustainable livelihoods: Lessons from early experience. London, Department for International Development.

Atkinson, R. (2000): The hidden costs of gentrification: Displacement in central London. Journal of Housing and the Built Environment, 15(4), str. 307-326.

Bacqué, M. H., Fijalkow, Y., Launay, L., in Vermeersch, S. (2011): Social mix policies in Paris: Discourses, policies and social effects. International Journal of Urban and Regional Research, 35(2), str. 256-273. DOI: 10.1111/j.1468-2427.2010.00995.x
Bianchini, F., in Parkinson, M. (1994): Cultural policy and urban regeneration: The west European experience. Manchester, Manchester University Press.

Bielderman, A., de Greef, M. H. G., Krijnen, W. P., in van der Schans, C. P. (2015): Relationship between socioeconomic status and quality of life in older adults: A path analysis. Quality of Life Research, 24(7), str. 16971705. DOI: 10.1007/s11136-014-0898-y

Bigio, A. G., in Licciardi, G. (2010): The urban rehabilitation of Medinas: The World Bank experience in the Middle East and North Africa. (= Urban Development Series Knowledge Papers 54935). Washington, World Bank.

Carnahan, D., Gove, W., in Galle, O. R. (1974): Urbanization, population density, and overcrowding: Trends in the quality of life in urban America. Social Forces, 53(1), str. 62-72. DOI: 10.1093/sf/53.1.62

Catley, A., Burns, J., Abebe, D., in Suji, O. (2014): Participatory impact assessment: A design guide. Somerville, MA, Tufts University. Dostopno na: https://fic.tufts.edu/wp-content/uploads/PIA-guide_revised-2014-3. pdf (sneto 20. 8. 2020).

Chen, Y. (2013): Neoliberal-inspired large-scale urban development projects in Chinese cities. V: Leary, M. E., in McCarthy, J. (ur.): The Routledge companion to urban regeneration, str. 97-107. London, Routledge.

City Council of Mashhad (2016): Report on the residents' problems of the central fabric of Mashhad (2016). Mashhad.

Costanza, R., Fisher, B., Ali, S., Beer, C., Bond, L., Boumans, R., idr. (2007): Quality of life: An approach integrating opportunities, human needs, and subjective well-being. Ecological Economics, 61(2-3), str. 267-276. DOI: 10.1016/j.ecolecon.2006.02.023

Cramer, V., Torgersen, S., in Kringlen, E. (2004): Quality of life in a city: The effect of population density. Social Indicators Research, 69(1), str. 103-116. DOl: 10.1023/b:soci.0000032663.59079.0b

Creswell, J. W. (1999): Mixed-method research: Introduction and application. V: Cizek, G. J. (ur.): Handbook of educational policy, str. 455-472. San Diego, Academic Press. DOI: 10.1016/b978-012174698-8/50045-x

Cullingworth, B., Caves, R. W., Cullingworth, J. B., in Caves, R. (2013): Planning in the USA: Policies, issues, and processes. London, Routledge. DOI: $0.4324 / 9780203126561$

Cummins, R. A. (1996): The domains of quality of life: An attempt to order the chaos. Social Indicators Research, 38, str. 303-328.

Dale, O. J. (1999): Urban planning in Singapore: The transformation of a city. New York, Oxford University Press.

Day, R. L. (1987): Relationships between life satisfaction and consumer satisfaction. Marketing and the quality of life interface. New York, Quorum Books.

Deller, S. C., Tsai, T. H., Marcouiller, D. W., in English, D. B. K. (2001): The role of amenities and quality of life in rural economic growth. American Journal of Agricultural Economics, 83(2), str. 352-365.

DOI: 10.1111/0002-9092.00161

Deng, C., in Ma, J. (2015): Viewing urban decay from the sky: A multi-scale analysis of residential vacancy in a shrinking US city. Landscape and Urban Planning, 141, str. 88-99.

DOI: 10.1016/j.landurbplan.2015.05.002

El Din, H. S., Shalaby, A., Farouh, H. E., in Elariane, S. A. (2013): Principles of urban quality of life for a neighborhood. HBRC Journal, 9(1), str. 8692. DOI: 10.1016/j.hbrcj.2013.02.007

Forouhar, A. (2016): Estimating the impact of metro rail stations on residential property values: Evidence from Tehran. Public Transport, 8(3), str. 427-451. DOI: 10.1007/s12469-016-0144-9 
Forouhar, A., in Hasankhani, M. (2018): The effect of Tehran metro rail system on residential property values: A comparative analysis between high-income and low-income neighbourhoods. Urban Studies, 55(16), str. 3503-3524. DOI: 10.1177/0042098017753089

Forouhar, N., in Forouhar, A. (2020): Evaluating the role of urban planners in participatory urban planning: A conceptual model of success in Iran. Archives of Business Administration and Management, 3, str. 135. DOI: $10.29011 / 2642-3243.100135$

Genov, N. (1998): Transformation and anomie: Problems of quality of life in Bulgaria. Social Indicators Research, 43(1-2), str. 197-209.

Gholizadeh, A. A., in Aminirad, M. (2018): Determining the optimal structure of Tehran municipality income basis based on risk and returns. Journal of Urban Economics and Management, 6(23), str. 81-95.

Güzey, Ö. (2013): Evaluation of urban regeneration as a government-assisted revenue strategy in Turkey: The global imperative. V: Leary, M. E., in McCarthy, J. (ur.): The Routledge companion to urban regeneration, str. 86-96. London, Routledge.

Hanson, R. F., Sawyer, G. K., Begle, A. M., in Hubel, G. S. (2010): The impact of crime victimization on quality of life. Journal of Traumatic Stress, 23(2), str. 189-197. DOI: 10.1002/jts.20508

Hosseyni, S. J. (2008): Constant public association in reconstruction and development of urban distressed areas. Mashhad, Iran, Sokhan Gostar.

Hsu, J.-Y., in Chang, W.-H. (2013): From state-led to developer-led? The dynamics of urban renewal policies in Taiwan. V: Leary, M. E., in McCarthy, J. (ur.): The Routledge companion to urban regeneration, str. 168-178. London, Routledge.

Huppert, F. A., Marks, N., Clark, A., Siegrist, J., Stutzer, A., Vitters $\varnothing$, J., idr. (2009): Measuring well-being across Europe: Description of the ESS well-being module and preliminary findings. Social Indicators Research, 91(3), str. 301-315. DOI: 10.1007/s11205-008-9346-0

Huschka, D., in Mau, S. (2005): Aspects of quality of life: Social anomie in South Africa. Discussion Papers / Wissenschaftszentrum Berlin für Sozialforschung, 2005(2).

Ibem, E. O. (2013): Bad memories and good prospects for housing-led urban regeneration projects in Nigeria. V: Leary, M. E., in McCarthy, J. (ur.): The Routledge companion to urban regeneration, str. 361-370. London, Routledge.

Imrie, R., in Thomas, H. (1997): Law, legal struggles and urban regeneration: Rethinking the relationships. Urban Studies, 34(9), str. 1401-1418. DOI: 10.1080/0042098975484

Johansson, S. (2002): Conceptualizing and measuring quality of life for national policy. V: Hagerty, M. R., Vogel, J., in Moeller, V. (ur.): Assessing quality of life and living conditions to guide national policy: The state of the art, str. 13-32. Dordrecht, Springer.

Kafashpor, A., Ghasempour Ganji, S. F., Sadeghian, S., in Johnson, L. W. (2018): Perception of tourism development and subjective happiness of residents in Mashhad, Iran. Asia Pacific Journal of Tourism Research, 23(6), str. 521-531. DOI: 10.1080/10941665.2018.1476392

Karl, M. (2000): Monitoring and evaluating stakeholder participation in agriculture and rural development projects: A literature review. Rim, Sustainable Development Department (SD), Food and Agriculture Organization of the United Nations (FAO).

Kheyroddin, R., Taghvaee, A., in Forouhar, A. (2014): The influence of metro station development on neighbourhood quality. International Review for Spatial Planning and Sustainable Development, 2(2), str. 64-75. DOI: 10.14246/irspsd.2.2_64

Kitchen, P., in Williams, A. (2010): Quality of life and perceptions of crime in Saskatoon, Canada. Social Indicators Research, 95(1), str. 33-61. DOI: $10.1007 /$ s11205-009-9449-2
Leary, M. E, in McCarthy, J. (2013): Introduction: Urban regeneration, a global phenomenon. V: Leary, M. E., in McCarthy, J. (ur.): The Routledge companion to urban regeneration, str. 21-34. London, Routledge.

Lee, Y.-J. (2008): Subjective quality of life measurement in Taipei. Building and Environment, 43(7), str. 1205-1215.

DOI: 10.1016/j.buildenv.2006.11.023

Li, G., in Weng, Q. (2007): Measuring the quality of life in city of Indianapolis by integration of remote sensing and census data. International Journal of Remote Sensing, 28(2), str. 249-267. DOI: 10.1080/01431160600735624

Lo, C. P. \& Faber, B. J. (1997): Integration of Landsat Thematic Mapper and census data for quality of life assessment. Remote Sensing of Environment, 62(2), str. 143-157. DOI: 10.1016/s0034-4257(97)00088-6

Map data (2020): Dostopno na: https://www.google.com/maps/ search/samen+district+mashhad/@36.2882319,59.6137988,1802m/ data=!3m1!1e3 (sneto 24. 9. 2020).

Marans, R. W., in Stimson, R. J. (2011): Investigating quality of urban life: Theory, methods, and empirical research (= Social Indicators Research Series 45). Dordrecht, Springer Science \& Business Media. DOI: 10.1007/978-94-007-1742-8

Marra, G., Barosio, M., Eynard, E., Marietta, C., Tabasso, M., in Melis, G. (2016): From urban renewal to urban regeneration: Classification criteria for urban interventions. Turin 1995-2015: Evolution of planning tools and approaches. Journal of Urban Regeneration \& Renewal, 9(4), str. 367-380.

Mashhad Municipality (2017): Statistical Yearbook of Mashhad. Dostopno na: https://mspl.mashhad.ir/parameters/mashhad/modules/cdk/ upload/content/portal_content/File/92/Year\%201396/ Final_Amarnameh_1395-96-8-27_Part1.pdf (sneto 31 7. 2020).

Mashhad Police Department (2016): Report on crime prevention and community safety of Mashhad. Mashhad, Police Department.

McCarthy, J. (2007): Partnership, collaborative planning and urban regeneration. Chesterfield, VB, Ashgate Publishing.

McCormick, K., Anderberg, S., Coenen, L., in Neij, L. (2013): Advancing sustainable urban transformation. Journal of Cleaner Production, 50, str. 1-11. DOI: 10.1016/j.jclepro.2013.01.003

Mielck, A., Vogelmann, M., in Leidl, R. (2014): Health-related quality of life and socioeconomic status: Inequalities among adults with a chronic disease. Health and Quality of Life Outcomes, 12(1), str. 1-10. DOI: $10.1186 / 1477-7525-12-58$

Morris, J. B., Tassone, V., De Groot, R., Camilleri, M., in Moncada, S. (2011): A framework for participatory impact assessment: Involving stakeholders in European policy making, a case study of land use change in Malta. Ecology and Society, 16(1), članek št. 12. DOI: $10.5751 /$ es-03857-160112

Munoth, N., Jain, R. K., Raheja, G., in Brar, T. S. (2013): Issues of sustainable redevelopment of city core: $\mathrm{A}$ study of developed and developing countries. Journal of The Institution of Engineers (India), Series A, 94(2), str. 117-122. DOI: 10.1007/s40030-013-0045-8

Musschenga, A. W. (1997): The relation between concepts of quality-of-life, health and happiness. The Journal of Medicine and Philosophy, 22(1), str. 11-28. DOI: 10.1093/jmp/22.1.11

$\mathrm{Ng}, \mathrm{M}$. K. (2005): Quality of life perceptions and directions for urban regeneration in Hong Kong. V: Shek, D. T., Chan, Y. K., in Lee, P. S. (ur.): Quality-of-life research in Chinese, western and global contexts (= Social Indicators Research Series 25), str. 441-465. Dordrecht, Springer. DOI: 10.1007/1-4020-3602-7_15 
Rabbani, G., Shafaqi, S., in Rahnama, M. R. (2018): Urban sprawl modeling using statistical approach in Mashhad, northeastern Iran. Modeling Earth Systems and Environment, 4(1), str. 141-149.

DOI: 0.1007/s40808-017-0404-y

Roberts, P., Sykes, H., in Granger, R. (2016): Urban regeneration. London, Sage.

Roche, C. J. (1999): Impact assessment for development agencies: Learning to value change. Oxford, Oxfam.

Rokicka, E.c, in Petelewicz, M. (2014): Subjective quality of life and socio-economic status. The case of Lodz inhabitants. Przeglad Socjologiczny, 63(2), str. 143-161.

Saghatoleslami, A. (2017): Study on contemporary interventions in the historical fabric of Mashhad. Creative City Design, 1(2), str. 28-42.

Samen Renewal Organization (2002): Report on the Samen Renewal Project. Mashhad, Iran.

Sarkheyli, E., Rafieian, M., in Taghvaee, A. A. (2016): Qualitative sustainability assessment of the large-scale redevelopment plan in Samen district of Mashhad. International Journal of Architecture and Urban Development, 6(2), str. 49-58.

Seik, F. T. (2001): Quality of life in cities. Cities, 1(18), str. 1-2.

Tallon, A. (2013): Urban regeneration in the UK. London, Routledge.

Teaford, J. C. (2000): Urban renewal and its aftermath. Housing Policy Debate, 11(2), str. 443-465. DOI: 10.1080/10511482.2000.9521373

von Hoffman, A. (2008): The lost history of urban renewal. Journal of Urbanism, 1(3), str. 281-301.

Western, J., in Lanyon, A. (1999): Anomie in the Asia Pacific region: The Australian study. V: Atteslander P., Gransow B., in Western J. (ur.): Comparative anomie research. Hidden barriers-hidden potential for social development, str. 73-98. Ashgate, Aldershot. DOI: 10.4324/9781315196046-5

Zuberi, D., in Taylor, A. (2013): Urban renewal in Vancouver, Canada. V: Leary, M. E., in McCarthy, J. (ur.): The Routledge companion to urban regeneration, str. 312-322. London, Routledge. 